\title{
Radiologinių tyrimų vertè kvėpavimo nepakankamumo atvejais
}

\author{
Laima Dobrovolskienè, Dovilè Budriūnaitè \\ LSMU MA Radiologijos klinika
}

Reikšminiai žodžiai: kvėpavimo nepakankamumas, radiologiniai tyrimai.

Santrauka. Straipsnyje aptariami pagrindinių radiologinių tyrimų vaizdų požymiai diferencijuojant kvėpavimo nepakankamumo priežastis esant grėsmingiems plaučių pažeidimams: ŪRDS, plaučių arterijos embolijai su infarktpneumonija, pneumotoraksui ir hemotoraksui, krūtinès traumai. Aprašoma lètinių plaučių ligų radiologinio vaizdo požymiai, priklausomi nuo ligos trukmės, sąlygojantys lètinį kvèpavimo funkcijos nepakankamumą.

\section{IVADAS}

Kvėpavimo nepakankamumas (KN) - tai patologinè būklè, kai kvejpavimo organai negeba pakankamai kraujo įsotinti deguonimi ar pašalinti anglies dioksido ir taip neužtikrina adekvačios oksigenacijos ir ventiliacijos [1]. KN diagnostika yra paremta kompleksiniu klinikinių, laboratorinių, funkcinių ir radiologinių tyrimų vertinimu. Tačiau kai kuriais, ypač ūminio kvėpavimo nepakankamumo, atvejais tiksli ir laiku atlikta radiologinio vaizdo interpretacija ligoniui gali būti lemtinga. Pagrindiniai radiologiniai tyrimai, naudojami KN diagnostikoje, yra plaučių rentgenografija ir kompiuterinè plaučių tomografija, nes jie padeda neinvaziniu būdu greitai ịtarti KN sukèlusią priežastị bei stebèti ligonio būklę. Radiologiniai tyrimai itin svarbūs ūminio KN priežasčiuc diagnostikai, ypač ūminio respiracinio distreso sindromo, taip pat nustatant trauminių pokyčiuc apimtį. Radiologinio vaizdo kitimas progresuojant lètinėms fibrozę sukeliančioms plaučių ar sisteminèms ligoms taip pat gali turèti ịtakos laiku pritaikyti tinkamą gydymo taktiką. Straipsnyje aptariami ir dažniausių lètinių ar sisteminių plaučių ligų, sukeliančių $\mathrm{KN}$, radiologinès diagnostikos ypatumai.

\section{ŪMINIS RESPIRACINIO DISTRESO SINDROMAS}

Ūminis respiracinio distreso sindromas (ŪRDS) yra sunki plaučių pažeidimo forma, lemianti apie 50 proc. mirtin- gumą [2]. ŪRDS - tai difuzinis alveolių pažeidimas, sutrikdantis alveoliu ir kapiliaru laidumą, dél to $\mathfrak{i}$ alveoles ir intersticini audinị priplūsta kraujo plazmos baltymų, skysčio bei neutrofiluc ir gali susiformuoti negrižtama alveolių membranų hialinizacija, fibroziniai antrinių plaučių skiltelių pokyčiai.

Radiologiniams tyrimams tenka labai svarbus vaidmuo ŪRDS diagnostikoje. Kartotinès krūtinès ląstos rentgenogramos (KR) padeda teisingai ịtarti ŪRDS diagnozę pacientams, kuriems pasireiškia būdingi ÜRDS klinikiniai požymiai, rasti ar patvirtinti ikiklinikines ŪRDS komplikacijas bei stebèti pirminių radinių progresavimą ar regresavimą. KR matomas vaizdas priklauso nuo ŪRDS stadijos, tačiau paprastai yra tipiškas nepriklausomai nuo ji sukèlusios priežasties [3]. Tuo tarpu kompiuterinè tomografija (KT) padeda ịvertinti gretutinių ligų foną, pokyčių, nustatytų KR, apimti, apibrèžti ÜRDS priežastị, tikslią pažeistos plaučiuc parenchimos lokalizaciją bei atlikti kiekybinę plaučių audinio bei kvėpuojamojo tūrio analizę [4-6]. Pastaruoju aspektu KT yra labai plačiai naudojama ÜRDS diagnostikoje ne tik klinikiniais, bet ir moksliniais tikslais [3].

Eksudacinejje, arba ūmineje, fazèje (1-7 dienos) pirmosiomis 24 val. paprastai krūtinès rentgenograma būna be pokyčių ar matyti pradinè neženkli infiltracija (1 pav.). Tačiau per kitas 24-72 val. pastebimi ryškūs pokyčiai, $\mathrm{KR}$ atrodantys kaip oro bronchogramos su intersticiniais susiliejančiais infiltratais (intersticine edema) (2 pav.). Iš 


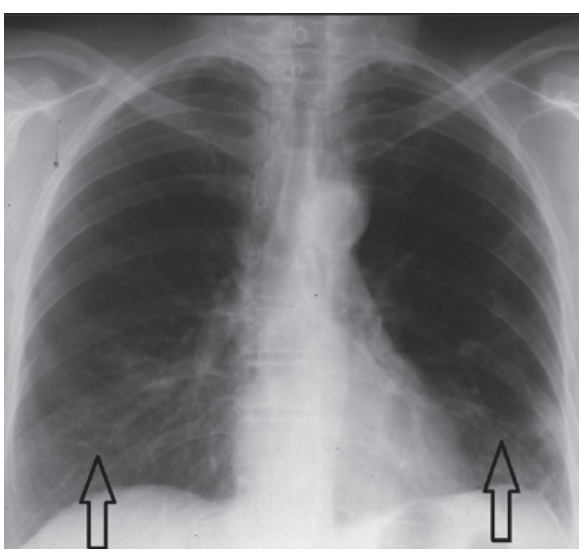

1 pav. 60 metu ligonès, sergančios sisteminiu ANCA vaskulitu, pirminejje krūtinès rentgenogramoje rodyklemis pažymèta neryški abipusè plaučių parenchimos infiltracija

pradžių pokyčiai matomi aplink plaučių šaknis, vẻliau išplinta i periferines dalis dažniausiai abipus ir simetriškai [4]. Ši vaizdą svarbu atskirti nuo kardiogeninès plaučiuc edemos, kuriai, be jau minètų pokyčių, būdingas skystis pleuros ertmèje, kardiomegalija bei tipinès Kerli (pertvarų linijos) [7]. Klasikinis ŪRDS vaizdas KT yra apibūdinamas kaip tankių skirtumai priekio nugaros kryptimi, vadinamas gravitacijos gradientu: ryškiausiais plaučių audinio sutankejjimas matomas užpakalinèse dalyse, priekinèse dalyse matomas normalus palučiuc audinys, o tarp jų - isiterpiantis „matinio stiklo" plotas. KR vertinant vaizdą galvos kojų kryptimi plaučių apatinèse dalyse matomas didejantis plaučiu audinio tankis, o vertinant kvèpavimo takus paplatėję bronchai [8]. Proliferacinejje stadijoje (8-14 dienų) krūtinès rentgenogramose paprastai vaizdas išlieka toks pats kaip pradinèse stadijose. Kartais gali išryškèti stambūs išplitę tinkliniai patamsèjimai, kurie rodo susiformavusius fibrozinius pokyčius, tačiau jie gali būti grịžtami. Šioje stadijoje rentgenogramose labai svarbu stebèti papildomai atsirandančius patamsèjimus, kurie gali padèti įtarti plaučiuc infekciją [4]. KT tyrimo metu proliferacinèje stadijoje matomi nehomogeniški netaisyklingi „matinio stiklo“ plotai bei sustorèjusios tarpskiltelinès pertvaros, supančios acinusus [8].

Jeigu pacientas išgyvena ūmiąją stadiją, fibrozinių pokyčių (membranų hialinizacijos), arba vèlyvosios, sta-
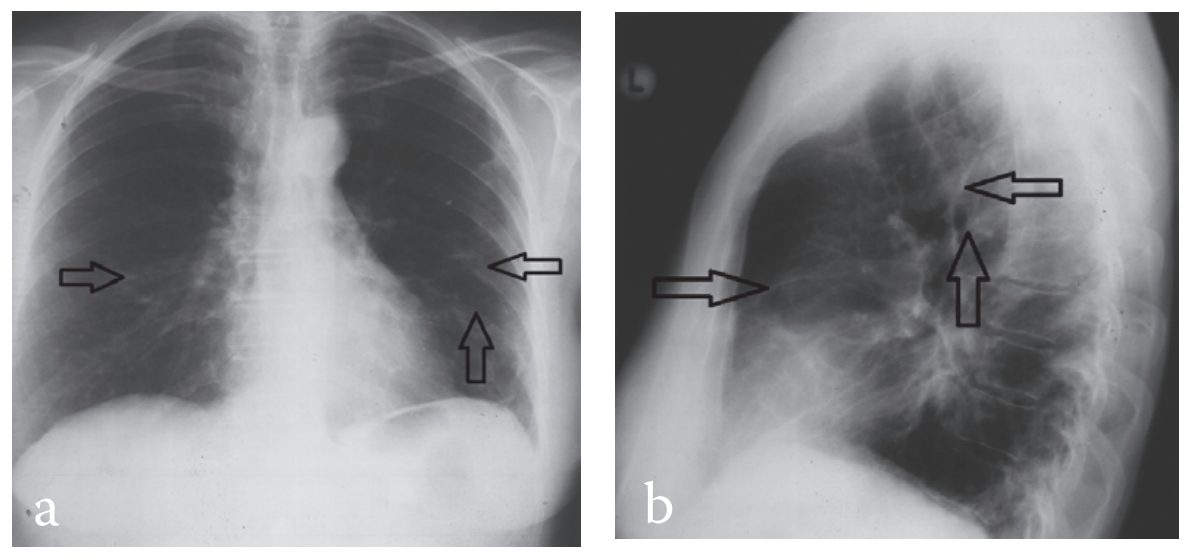

2 a. b pav. Tos pačios ligonès kartotinèse krūtinès rentgenogramose rodyklėmis pažymèti ryškejjantys intersticiniai, perivaskuliniai pokyčiai

dijos (>15 dienų) metu KR matomas išliekantis arba progresuojantis edemos vaizdas su „matinio stiklo" fone ryškèjančiais retikuliniais ir perivaskuliniais pokyčiais [4]. KT vaizduose ŪRDS hialinizacijos stadijoje matomas negrižztamai pakitęs netaisyklingos korinès deformacijos plaučių piešinys, „matinio stiklo" fone ryškejjančios antrinès trakcinès bronchektazès, sustorèjusios kraujagyslių sienelès bei galimos ịvairios komplikacijos: skysčio pleuros ar perikardo ertmèje sankaupos, pneumotoraksas ir kt. (3 pav.) $[8,9]$.

\section{PLAUČIŲ ARTERIJOS TROMBINĖ EMBOLIJA}

Plaučių arterijos trombinė embolija (PATE) - plaučių arterijos ar jos šakų okliuzija trombu, sutrikdanti įvairios apimties plaučių audinio kraujotaką ir sukelianti ūmini kvépavimo funkcijos nepakankamumą [1]. Diagnozę nustatyti sudètinga, bet svarbu, nes, laiku nediagnozavus PATE, ligonių mirštamumas siekia iki 30 proc., tuo tarpu skubiai nustačius diagnozę ir skyrus tinkamą gydymą antikoaguliantais, jis ženkliai sumažèja - iki 2-8 proc.

Ligonis tirti pradedamas įvertinant klinikinès PATE tikimybę pagal klinikinių bei laboratorinių tyrimų (Ddimerai) rodmenis, tačiau, esant net menkiausiai rizikai, visada atliekami radiologiniai tyrimai: plaučių arterijų KT angiografijos tyrimas, sušvirkštus intraveninės kontrastinès medžiagos. Ūminès PATE požymiai KT vaizduose gali būti labai įvairūs: plaučių arterijų spindyje matomi kontrastinès medžiagos prisipildymo defektai, kuriuos apteka kraujas, visiškas spindžio užkimšimas, trombas, su kraujagyslès sienele formuojantis smailų kampą, plūduriuojantys trombo komponentai, išsiplètęs kraujagyslès spindis, dešiniojo skilvelio perkrovos ir plautinès hipertenzijos požymiai (dešiniojo skilvelio išsiplètimas, tarpskilvelinès pertvaros išlinkimas ị kairę, plautinio kamieno skersmuo >29 mm). Didžiausią reikšmę radiologiniai tyrimai turi diagnozuojant grèsmingą PATE sąlygotą plaučiu infarktinę pneumoniją, plačius hipoventiliacijos defektus (nekaupiančios kontrastinès medžiagos pleišto formos konsolidacijos ar „matinio stiklo“ zonos periferijoje) (4 pav.).

Lètinès PATE požymiai KT vaizduose matomi kaip pasieniniai trombai, formuojantys buką kampą su kraujagyslès sienele, linijiniai ar netaisyklingi prisipildymo defektai kraujagysliu spindyje, netolygiai sustorèjusi plaučiuc arterijos sienelè, lokaliai susiaurèjęs kraujagyslès spindis ar dalinė okliuzija, susiaurèjęs kraujagyslès skersmuo, kalcinatai plaučiu arterijų sienelèse, geografinis (mozaikinis) plaučiu parenchimos vaizdas dèl netolygios perfuzijos, randiniai pokyčiai, diskinès reflektorinès atelektazès periferinèse plaučiuc dalyse po persirgtos infarktinès pneumonijos, dešiniojo skilvelio perkrovos požymiai, plautinès hipertenzijos požymiai [10].

Daugelio užsienio autorių tyrimų analizès duomenimis, daugiasluoksnès 
KTA jautrumas ir specifiškumas diagnozuojant PATE yra atitinkamai 53-100 proc., 81-100 proc. [11]. Taigi plaučiu arterijų KTA šiuo metu yra tiksliausias ir tinkamiausias radiologinis tyrimo metodas ankstyvai PATE diagnostikai.

\section{PNEUMOTORAKSAS, HEMOTORAKSAS}

Itariant pneumotoraksą pirmos eilès tyrimas visada yra KR, nes jis greitas, skleidžiantis mažą jonizuojančiąją apšvitą, neinvazinis ir nebrangus, suteikiantis apžvalginès informacijos apie įtariamą patologiją. Tačiau KT yra daug jautresnis tyrimas aptinkant spontaninio pneumotorakso priežastị (plaučių emfizemą, bulas, krūtinès sienos deformacijas), ypač svarbus diagnozuojant mažos apimties pneumotoraksą $[12,13]$. KR pneumotorakso požymiai: visceralinè pleura matoma kaip plona balta linija, už kurios subpleuriné juosta be plaučių piešinio; galimas plaučio kolapsas, tarpuplautis neturètu būti pastumtas, nebent pasireiškia itampos pneumotoraksas, traumos atveju gali būti poodinè bei tarpuplaučio emfizema, palučiu audinyje matyti nevienodo tankio netaisyklingos parenchimos kontuzijos zonos [14] (5 pav.).

Hemotorakso KR požymiai: bukas kostodiafragminis kampas, horizontalus skysčio ir oro paviršius, sunkiai diferencijuojama diafragma, tačiau atskirti hemotoraksą nuo kito pobūdžio skysčio pleuros ertmèje KR yra praktiškai neįmanoma [15]. Skysčio pleuros ertmejje tankio pokyčius padeda atskirti tik krūtinès ląstos KT, kurios vaizduose vidine aparato sistema išmatavus pokyčių zoną, kraujas būna apie $+35+70+90$ HU tankio (priklauso nuo suskystejjimo). Be to, KT aptinka kur kas mažesni skysčio kieki pleuros ertmèje negu KR [16].

\section{LÉTINI KVËPAVIMO NEPAKANKAMUMĄ SĄLYGOJANTI PLAUČIŲ FIBROZE்}

Plaučiu fibrozę (PF) gali lemti skirtingos priežastys, skatinančios jungia-
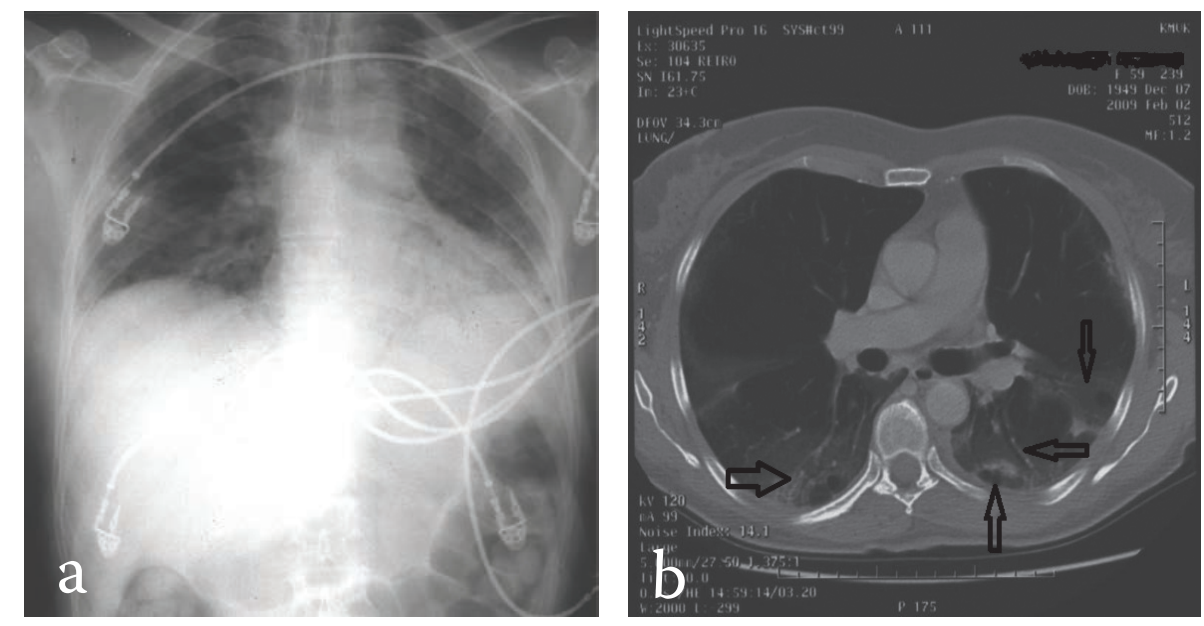

3 a, b pav. Tos pačios ligonès krūtinès rentgenogramoje ryškėjanti intersticinè plaučių edema (a) ir kompiuterinejje rentgenogramoje - netaisyklingos korinès deformacijos plaučiu piešinys, "matinio stiklo" fone ryškèjančios antrinès trakcinès bronchektazès, sustorejjusios kraujagyslių sienelès (b)
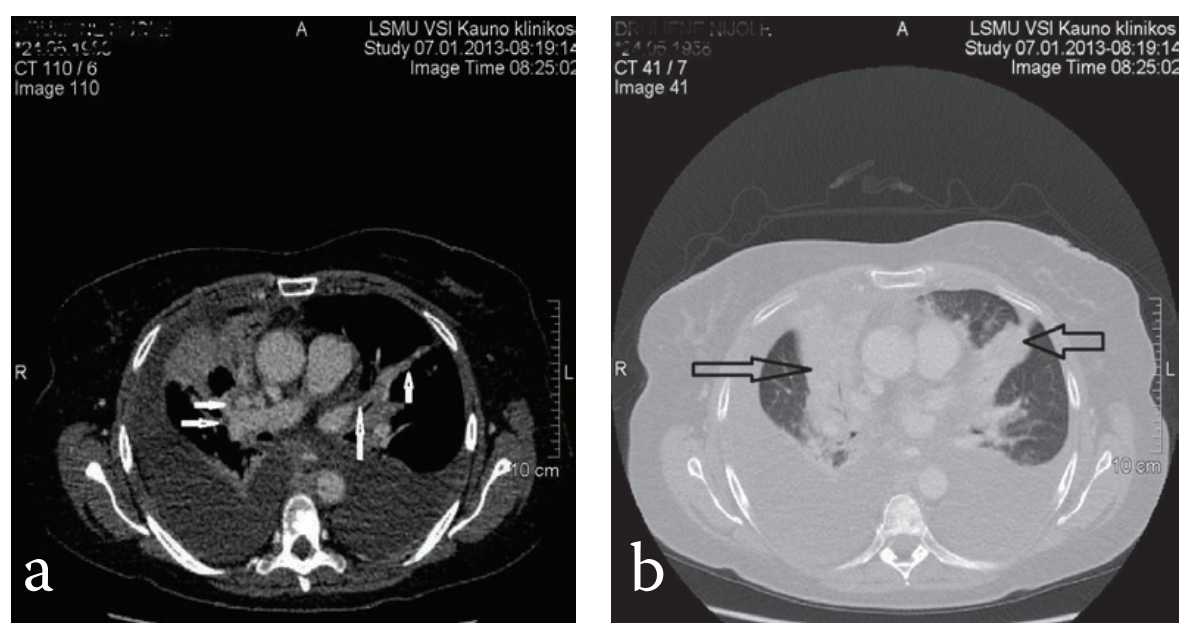

4 a, b pav. 46 metų dūstančios ligonès KT vaizdai: minkštujų audinių lange rodyklèmis pažymètos obturuotos segmentinès plaučių arterijos šakos (a); rodyklèmis pažymèta nekaupianti kontrastinès medžiagos subliuškusi parenchima - abipusė infarktpneumonija (b)

mojo audinio kaupimąsi plaučiuose. PF yra skiriama i̇ žinomos kilmès, dažniausiai sąlygotą sisteminių jungiamojo audinio ligu ar sukeltą pulmotropiniu toksinių medžiagu poveikio, ir idiopatinę [1]. PF diagnozè grindžiama klinikinès eigos, plaučiuc audinio biopsijos bei radiologinių tyrimų duomenimis. Pagrindinis radiologinis tyrimas, padedantis įtarti PF ir stebèti jos progresavimą yra krūtinès ląstos KT. Jos vaizduose matomi būdingi požymiai: ankstyvose stadijose - „matinio stiklo“ vaizdas (dažnai nèra specifiškas), vẻliau - retikuliniai ir cistiniai pokyčiai, tempimo (trakcinès) bronchektazès, suardyta korinè plaučiu piešinio deformacija, dèl netolygaus tarpskilteliniu pertvarų sustorèjimo (6 pav.). Radiologinių tyrimú duomenys dažnai priklauso nuo ligos trukmès bei ją sukèlusios priežasties, todèl dažniausiai PF nustatoma tik progresuojant ligai vèlyvose stadijose, ženkliai pablogèjus kvẻpavimo funkcijai, nes KR požymiai išryškèja daug vẻliau nei KT tyrimo vaizduose [17-19]. Todèl KT stebèti ligonius, sergančius sisteminèmis ar kitomis ligomis, sąlygojančiomis fibrozinius plaučių pokyčius ir lètini kvėpavimo funkcijos nepakankamumą, daug naudingesnè nei keletą kartų kartojamos KR. 


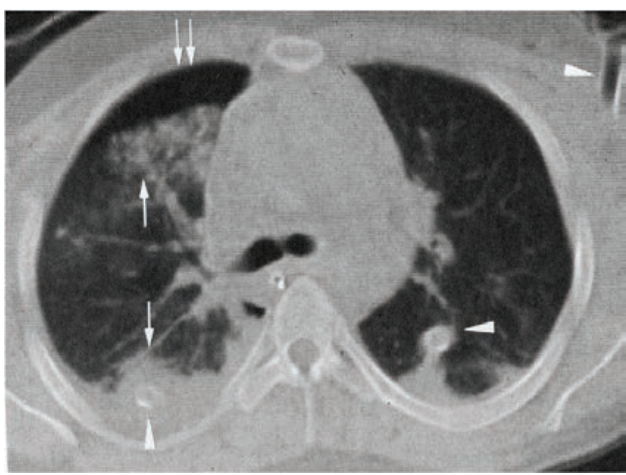

5 pav. 28 metu krūtinės traumą patyrusio ligonio kompiuterinejje tomogramoje rodyklėmis pažymètas pneumohemotoraksas, kontuzijos zonos
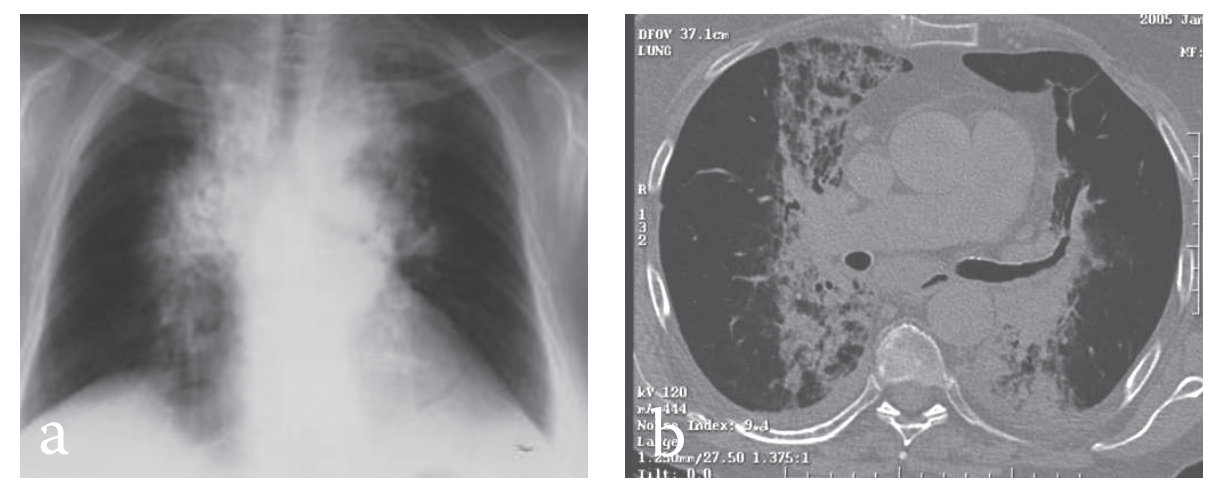

6 a, b pav. Dūstantis 68 metu ligonis po plaučių věžio gydymo: pospindulinè priešakniné plaučių fibrozè krūtinès rentgenogtamoje (a) ir kompiuterinèje tomogramoje (b)

\section{APIBENDRINIMAS}

Radiologiniai tyrimai kai kuriais ūminio (ŪRDS, PATE, traumos atvejai) ar lètinio (progresuojančios lètinę fibrozę sukeliančios ligos) KN atvejais vaidina išskirtinai svarbų vaidmeni ne tik nustatant KN priežastị, bet ir vertinant ligos eigą bei prognozę. Pastaruoju metu KT yra vienas svarbiausių plaučių neinvazinių diagnostinių tyrimų, nes šiuolaikinė daugiasluoksnès KT aparatūra greitai ir tiksliai padeda gauti detalios informacijos apie plaučių audinio būklę ūminių ligų atvejais, be to, skleidžia ženkliai mažesnę nei iki šiol jonizuojančiąją apšvita, todèl pasižymi mažesniu kenksmingumu. KR dažniausiai naudojama pirminiam apžvalginiam ịvertinimui bei ligos tolesnès eigos stebejjimui, bet jos diagnostiné verté ivvairiais $\mathrm{KN}$ atvejais daug mažesnè nei daugiasluoksnès KT.

\section{VALUE OF RADIOLOGICAL IMAGING IN CASES OF THE RESPIRATORY INSUFFICIENCY}

\section{LAIMA DOBROVOLSKIENEE, DOVILE BUDRIŪNAITE LUHS MA CLINIC OF RADIOLOGY}

Keywords: respiratory insufficiency, radiological imaging.

Summary. The article discusses the main radiological methods of investigation differentiating features in images of respiratory failure causes at threatening lung disorder ARDS, pulmonary embolism with infarction, pneumothorax and hemothorax, thoracic trauma. It also describes important signs in radiological images of chronic lung disease depending on the duration of the diseases, which result is chronic respiratory failure.

\section{LITERATÜRA}

1. Danila E, Zablockis R, Gruslys V, Šileikienè V, Žurauskas E et al. Klinikinè pulmonologija. Vaistu žinios; 2015.

2. Brun-Buisson C, Minelli C, Bertolini G, Brazzi L, Pimentel J, Lewandowski K, et al. Epidemiology and outcome of acute lung injury in European intensive care units. Results from the alive study. Intensive Care Med 2004;30(1):51-61.

3. Maunder RJ, Shuman WP, McHugh JW, Marglin SI, Butler J. Preservation of normal lung regions in the adult respiratory distress syndrome. Analysis by computed tomography. JAMA 1986;255(18): 2463-65.

4. Desai SR. Acute respiratory distress syndrome: imaging of the injured lung. Clin Radiol. 2002:57(1):8-17.

5. Desai SR, Wells AU, Suntharalingam G, Rubens MB, Evans TW, Hansell DM. Acute respiratory distress syndrome caused by pulmonary and extrapulmonary injury: a comparative CT study. Radiology. 2001;218(3):689-93.

6. Rouby JJ, Puybasset L, Nieszkowska A, Lu Q. Acute respiratory distress syndrome: lessons from computed tomography of the whole lung. Crit Care Med. 2003;31(4 Suppl):S285-95.

7. Sheard S, Rao P, Devaraj A: Imaging of acute respiratory distress syndrome. Respir Care 2012, 57:607-612.

8. Gluecker T, Capasso P, Schnyder P, Gudinchet F, Schaller MD, Revelly JP, Chiolero R, Vock P, Wicky S. Clinical and radiologic features of pulmonary edema. Radiographics. 1999;19(6):1507-31.

9. Goodman LR. Congestive heart failure and adult respiratory distress syndrome. New insights using computed tomography. Radiol Clin North Am. 1996 Jan;34(1):33-46.

10. Miliauskas $\mathrm{S}$, Eremininè $\mathrm{E}$, Jankauskas $\mathrm{A}$, Jurevičius $\mathrm{R}$, Jurkienè $\mathrm{N}$ et al. Plaučiu embolijos diagnostikos, gydymo ir profilaktikos rekomendacijos. Medicinos spaudos namai; 2013.

11. Rathbun SW, Raskob GE, Whitsett TL. Sensitivity and Specificity of Helical Computed Tomography in the Diagnosis of Pulmonary Embolism: A Systematic Review. Ann Intern Med. 2000;132:227-32.

12. Mitlehner W, Friedrich M, Dissmann W. Value of computer tomography in the detection of bullae and blebs in patients with primary spontaneous pneumothorax. Respiration. 1992. 59(4):221-7.

13. Lesur O, Delorme N, Fromaget JM, et al. Computed tomography in the etiologic assessment of idiopathic spontaneous pneumothorax. Chest. 1990 Aug. 98(2):341-7.

14. Seow A, Kazerooni EA, Pernicano PG et-al. Comparison of upright inspiratory and expiratory chest radiographs for detecting pneumothoraces. AJR Am Roentgenol. 1996;166 (2): 313-6.

15. Ho ML, Gutierrez FR. Chest radiography in thoracic polytrauma. AJR Am J Roentgenol. 2009;192 (3): 599-612.

16. Kaewlai R, Avery LL, Asrani AV et-al. Multidetector CT of blunt thoracic trauma. Radiographics. 2008;28 (6): 1555-70.

17. Hunninghake GW, Lynch DA, Galvin JR, et al. Radiologic findings are strongly associated with a pathologic diagnosis of usual interstitial pneumonia. Chest 2003; 124: 1215-1223.

18. Hansell DM, Bankier AA, MacMahon $\mathrm{H}$, et al. Fleischner Society: glossary of terms for thoracic imaging. Radiology 2008; 246: 697-722.

19. Johkoh T, Sakai F, Noma S, et al. Honeycombing on CT: its definitions, pathologic correlation, and future direction of its diagnosis. Eur J Radiol 2014; 83: 27-31. 